\title{
ABU YUSUF DAN PAJAK \\ (KONSEP DALAM KITAB AL-KHARAJ DAN RELEVANSINYA DA- LAM EKONOMI SAAT INI)
}

\author{
Arif Zunaidi \\ Institut Agama Islam Negeri (IAIN) Kediri \\ arifrunaidi@iainkediri.ac.id
}

\begin{abstract}
Abstrak:
Sebagai tokoh yang memiliki nama besar, Abu Yusuf memiliki karya fenomenal dalam bidang pajak, yaitu kitab Al-Kharaj. Kitab yang ditulis atas permintaan Khalifah Harun Ar-Rasyid ini digunakan sebagai pedoman dalam pengelolaan pajak. Sebagai salah satu sektor penting dalam penerimaan negara, pajak seharusnya tidak mendzolimi masyarakat dari besaran presentasenya. Tujuan dari penulisan ini adalah untuk mengetahui sejarah penulisan kitab Al-Kharaj dan isi kitabnya. Selain itu, tulisan ini juga untuk mengetahui konsep pajak yang ditulis Abu Yusuf dan utilitasnya dengan ekonomi saat ini. Metode yang digunakan dalam penulisan ini adalah metodologi pemikiran tokoh yang dilacak dari sikap, tulisan atau pun tanggapan pada suatu kasus fenomena yang terjadi pada masa itu. Untuk mengetahui latar belakang pemikiran Abu Yusuf tidak bisa mengesampingkan beberapa faktor yang ada, baik faktor internal maupun faktor eksternal yang menjadi pemicunya. Hasil penelitian menemukan bahwa pemikiran Abu Yusuf tentang pajak menjadi salah satu konsep yang dilaksanakan hingga saat ini. Konsepnya dipakai dan diaplikasikan dalam menentukan presentase penerimaan pajak oleh negara. Konsep Al-Kharaj digunakan dalam sektor penerimaan Pajak Bumi dan Bangunan (PBB), bea cukai. Dengan perhitungan presentasenya.
\end{abstract}

Kata kunci: Abu Yusuf, Kitab Al-Kharaj, Pajak, Pendapatan Negara

\begin{abstract}
:
As a well-known figure, Abu Yusuf has written a phenomenal work in taxation studies, namely al-Kharaj. This book which written at the request of the Caliph Harun ar-Rashid is used as a guide in tax management efforts. As one of the important sectors in state revenue, taxes should not deceive the public from their percentage. The article aims to find out the context of Al-Kharaj and its contents. Therefore, this study seeks to reveal the thoughts of Abu Yusuf and his background which were traced through his attitudes, writings, and responses to a case that occurred at that time. In addition, the paper is also to find out the tax concept initiated by Abu Yusuf and its practice in economic conditions' today. The results of this study found that Abu Yusuf's thought about taxes is one of the concepts that is still used today. This concept is applied in determining the percentage of tax revenue by the state. The Al-Kharaj concept is also used in the land and building tax (PBB) and customs revenue sectors.
\end{abstract}

Keywords: Abu Yusuf Thought, Kitab al-Kharaj, Taxation, State Income.

\section{PENDAHULUAN}

Pajak, sebagai salah satu sumber pendapatan negara yang harus dikelola dengan baik, sehingga dapat memberikan hasil yang maksimal untuk kepentingan dan kesejahteraan masyarakat. 


\section{Abu Yusuf dan Pajak (Konsep Dalam Kitab Al-Kharaj dan Relevansinya}

Sebagai sumber pendapatan negara, pajak memiliki fungsi dalam membiayai pengeluaranpengeluaran negara. Dimanfaatkan guna menjalankan aktifitas dan tugas rutin negara. Selain itu juga dimanfaatkan untuk meningkatkan pembangunan infrastruktur negara dan umum yang dapat dinikmati oleh masyarakat. Pembangaunan membutuhkan biaya. Biaya-biaya tersebut diperoleh sebagai penerimaan negara dari sektor pajak. ${ }^{1}$

Kontribusi pajak dalam tatanan penerimaan negara menjadi tulang punggung dalam menjalankan pemerintahan negara. Selain perannya yang vital dalam kontribusi penerimaan pendapatan, pajak juga sebagai berperan penting dalam menjaga kedaulatan negara, khususnya sebagai sumber penerimaan dalam APBN. ${ }^{2}$

Masyarakat turut berperan penting memberikan kontribusi pada pendapatan negara melalui pajak yang dibayarkan kepada negara. Melalui kontribusiya, masyarakat berperan aktif dalam mensukseskan pembangunan infrastruktur negara.

Dalam sejarah Islam, pelaksanaan pajak telah ada sejak masa Nabi Muhammad SAW dan penerapannya masih terus berlanjut hingga saat ini. Di awal perkembangan agama islam di jazirah Arab, pada Dinasti Abbasiyah, lahir Abu Yusuf sebagai seorang ulama sekaligus qodhi yang menulis kitab tentang perpajakan. Karya beliau ini menjadi fenomenal karena komprehensif dan cocok diterapkan dalam negara yang memandang bahwa pajak adalah salah satu penerimaan negara paling utama. ${ }^{3}$

Kitab Al-Kharaj megemukakan pemikiran tentang pentingnya penerapan sistem pajak dari model wadrifah ke pajak gaya muqasamah. Wadrifah memiliki model pungutan berdasarkan pada nilai tetap. Sedangkan muqasamah memiliki gaya pungutan berdasarkan pada nilai yang selalu berubah atau tidak tetap. Pertimbangannya berdasarkan pada perubahan dari presentase penghasilan atau tingkat kemampuan individu dalam membayar pajak. ${ }^{4}$

Perkembangan ekonomi saat ini berjalan sangat cepat. Semakin besar suatu negara, semakin besar pula dana yang dibutuhkan untuk menjalankan pemerintahan. Kebutuhan negara dalam memenuhi anggaran belanja haruslah dapat ditopang dari pendapatan negara. Pajak adalah salah satu penghasilan negara dalam proses untuk memenuhi kebutuhan belanja.

Praktik pajak saat ini begitu beragam. Setiap usaha hampir semua kena tarif pajak. Tarifnya pun bervariasi. Jika dihadapkan pada kitab Al-Kharaj, bagaimanakah prakti pajak saat ini?

\footnotetext{
1 "Fungsi Pajak", https://www.pajak.go.id/id/fungsi-pajak, diakses pada 15 Februari 2021.

2 "Menkeu: Pajak Merupakan Tulang Punggung Nanal", https://www.kemenkeu.go.id/publikasi/berita/menkeu-pajak-merupakan-tulang-punggung-nasional// diakses pada 15 Februari 2021

${ }^{3}$ Rachmatullah Oky , "Teori Pajak Menurut Abu Yusuf Sebuah Alternatif Solusi Perpajakan Di Indonesia". Iqtishoduna Vol. 8 No. 1 April 2019

${ }^{4}$ Abd. Kholik Khoerulloh, Omay Komarudin, Lukman Fauzi Abdillah, "Konsep Pajak Dalam Perspektif Abu

Yusufdan Asy-Syatibi”. An-Nisbah: Jurnal Ekonomi Syariah Volume 07, Nomor 01, April 2020
} 
Inilah yang menjadi dasar pemikiran dari tulisan ini. Untuk melihat konsep pajak dalam kitab $A l$ Kharaj dan praktiknya pada ekonomi saat ini.

\section{KAJIAN PUSTAKA}

\section{Konsep Kharaj}

Pajak, secara etimologis dimaknai sebagai al-kharaj. Yaitu tarikan yang diwajibkan pada tanah yang ditaklukkan melalui peperangan. ${ }^{5}$ hasil bumi yang dikenakan pajak atas tanah yaitu tanah yang dimiliki oleh non muslim. ${ }^{6}$

Selain pengertian tersebut, kharaj juga dimaknai sebagai uang sewa atas tanah yang dibebaskan oleh orang muslim. ${ }^{7}$

Secara etimologi, pajak diartikan sebagai iuran wajib untuk dibayarkan kepada negara dan dimanfaatkan sebesar-besarnya untuk kepentingan negara.

Islam mengenal beberapa jenis pajak, antara lain:

1. Jizyah. Pajak yang dikenakan atas non muslim sebagai jaminan yang diberikan oleh Negara Islam. ${ }^{8}$

2. Kharaj, jenis pajak atas tanah yang ditaklukkan melalui jalan perang.

3. Usyr, pajak perdagangan atau bea cukai (pajak impor dan ekspor).

\section{METODE PENELITIAN}

Sebagai tulisan yang mengaji pemikiran seorang tokoh ekonomi Islam dan kaitannya dengan kejadian saat ini, maka pendekatan yang digunakan dalam penulisan ini adalah metodologi pemikiran tokoh. Ada hal-hal khusus yang harus digunakan dalam menelaah tokoh, antara lain: Ada bukti dari pemikiran tokoh tersebut. Baik dalam bentuk sikap, tulisan atau pun tanggapan pada suatu kasus. Hasil pemikirannya dapat dilacak manifestasinya. Latar belakang yang mempengaruhi pemikirannya, baik faktor internal yang meliputi agama, ideologi, subjektifitas dan responnya atas segala persoalan. Sedangkan faktor eksternal dipengaruhi atas sosial ekonomi, budaya, politik, dan hukum yang berlaku pada saat itu.

Sedangkan pendekatan lain yang dapat digunakan untuk melihat pemikiran tokoh adalah dengan melihat subjektifitas, menelaah pemikiman tokoh, bagaimana ia menghasilkan

\footnotetext{
${ }^{5}$ M. Abdul Mannan, Teori \&Praktek Ekonomi Islam, Jakarta: PT. Dana Bhakti Wakaf, 1993, hlm.250.

${ }^{6}$ Irfan Mahmud Raeeana, Sistem Ekonomi Pemerintahan Umar Ibn Khattab, Yogyakarta:PustakaFirdaus, cet. 1, 1990, hlm. 118.

${ }^{7}$ Rodney Wilson, "Islamic Business Theory and Practice", (terj.) J.T. Salim, Bisnis IslamMenurut Islam Teo ri dan Praktik, Jakarta: PT. Intermasa, cet. 1, 1988, hlm. 128

8 Adiwarman Karim, Sejarah Pemikiran Ekonomi Islam, Jakarta: PT. Pustaka Pelajar, cet.2, 2002,hlm. 31
}

FENOMENA, Vol. 20 No. 1 (Januari - Juni 2021) | 63 


\section{Abu Yusuf dan Pajak (Konsep Dalam Kitab Al-Kharaj dan Relevansinya}

pemikirannya. Pendekatan lainnya adalah subjektifitas, yakni menelaah terhadap hasil pemikiran dan hubungannya dengan lingkungan yang mempengaruhinya ${ }^{9}$.

Metode yang dipakai dalam tulisan ini adalah kombinasi antara metode subjektif dan metode objektif. Dengan pilihan metode tersebut, maka titik tekan dalam penulisan ini adalah bagaimana mengungkap pemikiran Abu Yusuf melalui karya-karyanya, khususnya kita Al-Kharaj . Selain itu juga mengkaji biografinya, karena yang akan mempengaruhi pemikiran-pemikirannya. Selanjutnya adalah memahami korelasi pemikirannya yang tertuang dalam kitab Al-Kharaj dan hubungannya dengan praktik pajak saat ini.

\section{PEMBAHASAN DAN DISKUSI}

\section{Profil Abu Yusuf}

Ya'Qub bin Ibrahim bin Habib bin Khunais bin Sa'ad Al-Anshari Al-Jalbi Al-Kufi AlBaghdadi adalah nama lengkapnya. Abu Yusuf adalah nama panggilan dan nama yang dikenal saat ini jika berbicara tentang pajak dalam islam. Beliau lahir Kufah (tahun $113 \mathrm{H}$ ), wafat $(182 \mathrm{H})$ di Baghdad. ${ }^{10}$

Memiliki nasab yang terhubung dengan sahabat Rasulullah saw, Sa'ad Al-Anshari, dari pihak ibu, memberikan tanggung jawab dalam tindak-tanduk untuk menyesuaikan dengan nasabnya. Sebagai anak yang lahir di keluarga pas-pasan, namun ia memiliki passion pada ilmu pengetahuan. Minatnya inilah yang menuntunnya untuk terus belajar dan berguru pada ulamaulama besar. Ditambah lagi dengan lingkungan yang mendukung akan minatnya tersebut, yaitu kota Kufah. Sebagai kota peradaban dan pusat ilmu-ilmu Islam, minatnya pada ilmu pengetahuan memiliki andil dalam membentuk pemikirannya.

Abu Muhammad Atho bin as-Saib Al-Kufi, Sulaiman bin Mahran Al-A'masy, Hisyam bin Urwah, Muhammad bin Abdurrahman bin Abi Laila, Muhammad bin Ishaq bin Yassar bin Jabbar, dan Al-Hajjaj bin Arthah adalah guru-gurunya yang telah memberinya banyak pemahaman, pemikiran dan pengetahuan. Abu Yusuf juga berguru pada pendiri Madzhab Hanifah, Abu Hanifah. Abu Yusuf pun termasuk tokoh yang paling getol menyebarkan madzhab ini. Sehingga ia pun dikenal sebagai salah satu tokoh yang berjasa dalam mengembangkan madzhab Hanifiah dalam islam. $^{11}$

Berkat ketekunan, niat dan minatnya yang besar pada ilmu pengetahuan, menjadikannya sebagai tokoh yang alim. Berkat nama-nama besar dari guru-guru sebagai pembimbing ditambah

\footnotetext{
${ }^{9}$ Crane Brinton, Pengantar Ilmu Politik. (Bandung: Binadipta, 1980), h. 15.

${ }_{10}$ Rahmani Timorita Yulianti, "Pemikiran Ekonomi Islam Abu Yusuf". MUQTASID Jurnal Ekonomi dan Perbankan Syariah, Vol 1, No 1 (2010)

11 Alimin Mesra, "Kajian atas Kredibilitas Imam Abu Hanifah di Bidang Hadis". AL-FIKR Volume 14 Nomor 3 Tahun 2010
}

64 | FENOMENA, Vol. 20 No. 1 (Januari - Juni 2021) 
kecerdasannya, membuat Abu Yusuf dihormati oleh banyak kalangan, tidak hanya dari kalangan ulama, tapi juga kalangan teknokrat dan masyarakat umum.

Pendapatnya banyak dipakai dan dijadikan acuan dalam pengambilan keputusan. Setiap ada masalah, banyak orang yang datang untuk meminta fatwa, juga pendapatnya. Tak jarang orang yang datang itu menetap untuk menuntut ilmu kepadanya. Muhamammad bin Al-Hasan Al-Syaibani, Ahmad bin Hanbal, Yazid bin Harun Al-Wasithi, Al-Hasan bin Ziyad Al-Lu'lui, dan Yahya bin Adam Al-Qarasy termasuk ulama-ulama yang pernah berguru kepadanya.

Dari kalangan teknokrat juga memuliakannya. Tercatat dalam sejarah Dinasti Abbasiyah, khalifah Harun ar-Rasyid, menempatkan beliau sebagai Ketua Mahkamah Agung (Qadhi alQudhah) sebagai bentuk penghormatan akan keluasan pengetahuan dan kedalaman ilmunya.

\section{Karya Pemikiran}

Sebagai tokoh yang dinilai memiliki peran penting dalam pengambilan keputusan di Mahkamah Agung, Abu Yusuf memiliki banyak karya sebagai bentuk respon atas gejala dan problematika yang terjadi di masyarakat, baik yang berkaitan dengan tatanan sosial, juga yang berkaitan dengan masalah agama.

Salah satu karya Abu Yusuf yang terkenal adalah kitab al-Atsâr. Kitab ini banyak memuat tentang pendapat dan pemikiran berkaitan dengan keyakinan dan aturan yang ada dalam faham Hanafi. Keterangan di dalamnya banyak memuat tentang kaidah-kaidah dan hukum fiqih dalam Madz̧ab Hanafi. Atas tulisannya dalam kitab inilah Abu Yusuf diangkat menja di qâdli al-qudlât pada masa pemerintahan Harun Ar-Rasyid pada masa Abbasiyah. ${ }^{12}$ Kealiman dan tingginya pemahaman tentang ilmu menjadikannya orang yang tepat memangku jabatan sebagai Hakim Agung.

Ikhtilâf Abî Hanîfah wa Ibn Lailâ adalah kitab lain yang juga dikenal sebagai salah satu karya Abu Yusuf yang terkenal. Dalam kitab tersebut memuat berbagai macam perbandingan pendapat antara Abû Hanifah dan Abû Lailâ, guru Abu Yusuf.

Al-Radd 'ala Siyâr al-Auza'̌̀ adalah kitab lain yang dimiliki Abu Yusuf. Kitab ini merupakan kitab bantahan atas pendapat al-Auzâ’i. Dalam sejarah keilmuan islam, jika seorang ahli ilmu tidak mensetujui pendapat ilmuwan lain, mereka akan membuat karya tandingan sebagai bantahan atas pendapat tersebut. Demikianlah yang dilakukan oleh Abu Yusuf. Al-Radd 'ala Siyâr al-Auza'î ini memiliki isi tentang bantahan-bantahan Abu Yusuf atas pemikiman al-Auzâ', seorang qâdlì di Syam (Siria).

\footnotetext{
12 "Pemikiran Abu Yusuf soal Ekonomi Negara dalam Kitab Al-Kharaj", https://www.nu.or.id/post/read/101873/pemikiran-abu-yusuf-soal-ekonomi-negara-dalam-kitab-al-kharaj diakses pada 20 Februari 2021
}

FENOMENA, Vol. 20 No. 1 (Januari - Juni 2021) | 65 


\section{Abu Yusuf dan Pajak (Konsep Dalam Kitab Al-Kharaj dan Relevansinya}

Kitab al-Jawâmi' adalah kitab yang berisi perdebatan tentang kedudukan ra'yu dan 'aql dalam hukum Islam. Masalah ra'yu dan 'aql adalah perdebatan yang tiada habis dibicarakan dalam sebuah kajian Filsafat Islam. Kitab ini aslinya adalah surat menyurat yang pernah ditulis Abu Yusuf untuk Yahya ibn Khâlid al-Barmâki, Perdana Menteri dari Khalifah Harun al-Râsyîd. Namun karena isinya yang menarik untuk diketahui oleh masyarakat umum, maka surat-surat tersebut dikumpulkan dan disatukan dalam satu kitab tersendiri, yaitu Kitab al-Jawâmi'.

Masih ada kitab lain yang ditulis oleh Abu Yusuf yang berkaitan tentang adab yang harus dilakukan seorang hakim. Kitab tersebut adalah Adab al-Qadlî. Dalam kitab tersebut menjelaskan secara rinci adab, etika atau perbuatan-perbuatan yang harus dimiliki oleh seorang hakim. Sebagai seorang hakim agung, tentunya mempunyai beban berat yang harus ditanggung. Ada etika yang harus dimiliki karena jabatan qodbi adalah panutan bagi masyarakat. ${ }^{13}$

Sedangkan kitab paling fenomenal adalah Kitab Al-Kharaj. Kitab terpenting dalam kehidupan Abu Yusuf dalam kaitannya dengan peran pemerintah dalam memberikan kemakmuran masyarakatnya. Dalam kitab Al-Kharaj ini menuturkan banyak hal tentang tata kelola pajak dan cukai yang harus dilakukan oleh pemerintah dalam memberikan keadilan dalam membayar pajak kepada pemerintah.

Sebagai sebuah kitab terlengkap yang memuat tentang aturan-aturan yang harus dilaksanakan menteri keuangan dan jajarannya untuk menghimpun pendapatan yang diperoleh dari sektor kharrâj, 'usyr dan jïzyah.

Al-Kharaj adalah buku pertama yang membahas masalah pajak dan tata kelolanya, khususnya di masa Dinasti Abbasiah. Sebagai buku pertama, cakupannya komprehensif, memuat panduan tata kelola keuangan negara.

Sebagai kitab yang lahir atas permintaan Harûn al-Rasyîd sebagai khalifah, kitab ini merupakan sarana untuk membuat SOP dalam pengelolaan pajak agar para pegawai pemerintahan, khususnya bagian keuangan terhindar dan tidak melakukan perbuatan al-dhulm.

Cakupan pembahasan dalam al-Kharāj paling banyak adalah masalah pajak, jizyah, dan penjelasan tentang beberapa persoalan yang berkaitan dengan administrasi pengelolaannya.

Dasar kharäj sebenarnya harta yang dikeluarkan oleh pemilik tanah untuk diberikan kepada negara. Atau dalam pengertian lain, kharaj ini dimaknai sebagai beban yang dibayarkan atas pajak tanah pertanian dan hasil bumi. ${ }^{14}$

Kitab al-Kharāj ini memuat beberapa bab. Dimulai dari nasihat ditujukan kepada para pemimpin dan para putra mahkota yang nantinya akan menjadi pemimpin periode setelahnya.

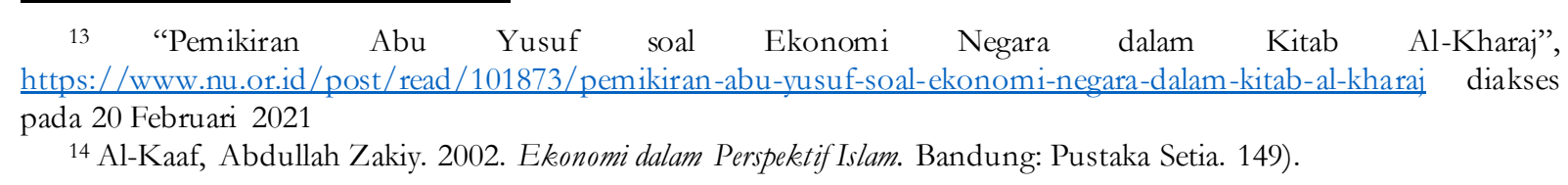


Nasihat-nasihat yang diberikan ini berisi tentang tugas yang diemban oleh penguasa atau pegawai pemerintahan yang didukung dengan haditst marfü' untuk memperkuat nasihatnya. ${ }^{15}$

Bab selanjutnya membahas tentang hukum dan kaidah-kaidah berkaitan dengan distribusi kekayaan, harta yang diperoleh dari rampasan perang, hak dan kewajiban dari kepemilikan tanah, pajak atas kepemilikan tanah, pajak-pajak yang dibebankan atas hasil pertanian.

Selain hal diatas, dalam kitab tersebut juga memuat tentang beberapa pajak lain, seperti 'ushr, zakat atau sadaqab'.

Disinggung juga dalam kitab al-kharaj tentang konsep jizyah. Secara umum, jizyah dimaknai sebagai pajak yang dibebankan kepada mereka yang non muslim, namun mereka menetap dan tinggal di negara Islam. Jiøyah adalah pajak yang dipungut atas perlindungan mereka, baik perlindungan dalam beragama, juga perlindungan atas harta yang dimiliki. Selain itu, jizyah juga merupakan jaminan keamanan soasial atas kehidupan mereka di negara Islam. ${ }^{17}$

Selain pebahasan tersebut, al-kharaj juga membahas tentang gaji yang diberikan pemerintah kepada para pegawai pemerintahan. Menyinggung juga kebijakan fiskal yang harus dijalankan oleh pemerintah, membicarakan pendapatan negara yang diperoleh dari devisa, juga mengatur tentang kesejahteraan non-muslim yang berada di negara Islam.

Seperti yang sudah dijelaskan di awal, bahwa konsep al-kharaj pada dasarnya membahas pajak yang dipungut atas tanah yang ditempati di negara islam. Dalam praktiknya, kharraj tidak hanya tentang pajak tanah, namun juga dinilai sebagai salah satu pemasukan pada keuangan publik (al-amwâl al-âmmah) juga termasuk dalam keuangan khusus (al-amwâlal-khâshah). ${ }^{18}$

Dinilai seebagai sumber pemasukan publik, karena dalam praktiknya juga menerima pemasukan dari sumber lain, yaitu ghanimah ${ }^{19}$, fai, ${ }^{20}$ al-jizyyah ${ }^{21}$, "usyr al-tijârah ${ }^{22}$ dan shadaqah. Sedangkan pendapatan sektor khusus, didapat dari sewa tanah yang dikelola oleh pihak asing.

Lebih jauh, jika melihat dari dua faktor yang muncul dalam pendapatan dari sektor alkharaj, maka ketentuan-ketentuan tersebut saat ini termasuk dalam pemasukan negara dari sektor

\footnotetext{
${ }^{15}$ Dedy Sumardi, "Legitimasi Pemungutan Jizyah Dalam Islam:Otoritas Agama Dan Penguasa”. Media Syariah, Vol. XV No. 2 Juli-Desember 2013

16 Rahmani Timorita Yulianti, "Pemikiran Ekonomi Islam Abu Yusuf". MUQTASID Jurnal Ekonomi dan Perbankan Syariah, Vol 1, No 1 (2010)

${ }^{17}$ Muhammad Sadam, Ekonomi Islam (Jakarta: Taramedia, 2002), hlm. 62

18 Tina Arfah, Putri Jamilah, "Keuangan Publik Dalam Perspektif Ekonomi Islam". Jurnal ISLAMIKA, Vol. 3, No. 2 (2020): $14-23$

19 Ghanimah adalah hasil rampasan perang

${ }^{20} \mathrm{Fa}^{\prime} i$ adalah harta rampasan perang yang diperoleh dari suatu negeri/ wilayah tanpa terjadi peperangan

21 Pajak per kapita yang diberikan oleh penduduk non-Muslim pada suatu negara di bawah peraturan Islam

${ }^{22}$ Bea aukai perdagangan
} 


\section{Abu Yusuf dan Pajak (Konsep Dalam Kitab Al-Kharaj dan Relevansinya}

pajak penghasilan (common taxation). pajak penghasilan adalah pajak yang dibebankan atas penghasilan, baik perorangan, perusahaan maupun badan hukum. ${ }^{23}$

Guna mengoptimalkan pemasukan negara dan untuk tidak terfokus hanya pada selain dari pajak, Abu Yusuf menyarankan untuk memperhatikan sektor lain, yakni dengan cara melakukan pengoptimalan pengelolaan sektor alam melalui pengelolaan lahan dan sumber irigasi yang dimiliki oleh negara. Dengan mengoptimalkan dua sumber daya alam tersebut, maka pemasukan negara dari sektor selain pajak akan meningkat. Dua sektor tersebut jika dikelola dengan benar, maka dapat dilakukan dengan cara pembukaan lahan baru untuk pertanian dan membangun irigasi yang memadai. Dua hal tersebut jika dikembangkan dan dikelola dengan benar, maka penghasilan sektor pertanian akan meningkat. Jika penghasilan petani meningkat, maka pajak yang dipungut oleh negara juga akan ikut meningkat.

Selain dua hal tersebut, untuk meningkatkan perekonomian negara dan memacu pertumbuhan ekonominya, negara dapat membuka lapangan kerja baru dan menyediakan tenaga kerja yang terampil melalui pelatihan-pelatihan yang diberikan oleh negara.

Guna memenuhi kebutuhan negara, pemerintah perlu membangun hubungan baik antar penduduknya. Kaum dzimmi dan umat islam harus bisa disandingkan, bahu-membahu dalam hal produktif agar ekonomi meningkat. Ketika ekonomi meningkat, maka negara akan menerima pemasukan dari sektor al-kharaj dan jizyah.

Dalam negara Islam, penduduknya dibagi atas tiga hal: rakyat, pemimpin dan lembagalembaga yang ada dalam pemerintahan. Tiga pelaku dalam perekonomian negara ini jika bahumembahu, maka akan menghasilkan sebuah tatanan ekonomi yang akan memajukan perekonomian negara. Rakyat berperan dalam kegiatan ekonominya, pemimpin dalam kebijakan-kebijakan yang diambil untuk masyarakatnya, dan lembaga-lembaga pemerintahan dari menjalankan kebijakan yang telah ditetapkan oleh pemerintah.

Dalam pengelolaan pendapatan negara, lembaga di pemerintahkan sesuai dengan job disk masing-masing lembaga. Contohnya, departemen yang bertugas khusus menerima pendapatan dari sektor jizyah, tugasnya menyesuaikan dan harus mengetahui rasio yang harus diterima dari jizyah. Pada bagian penerimaan ghanimah juga harus mengetahui pengelolaan ghanîmah paling bagus untuk mengoptimalkan pemasukan bendahara negara, juga penentuan standarisasi dari gaji pegawai pemerintahan. Selain itu juga harus mempertimbangkan tunjangan yang akan diberikan kepada khalifah dan perangkat yang ada di pemerintahan.

Pemerintah memiliki kewajiban dalam mengatur dan menetapkan tanah terlantar untuk dimanfaatkan dan dikuasai, apakah nantinya memiliki penetapan sebagai tanah dengan Hak Milik,

${ }^{23}$ Albertus Tandilino, "Penerapan Pajak Dalam Meningkatkan Penerimaanpajak Penghasilan Final Sektor Umkm Di Kotakendari”. Jurnal Progres Ekonomi PembangunanVoume 1 Nomor 1, 2016 
Hak Guna Usaha, Hak Guna Bangunan, dan Hak Pakai, atau hak yang lainnya. Karena penetapan atas tanah yang dikuasai dan berpindah kepemilikan nantinya akan berpengaruh pada penerimaan pajak dan peraturan lain yang berhubungan dengan pemasukan negara.

Pemerintah juga memperhatikan dalam hal kepemilikan. Konsep kepemilikan diatur dengan sedemikian rupa. Pemerintah mengatur kepemilikan akan modal, kepemilikan aktual, kepemilikan individu, kepemilikan khusus terhadap barang bergerak, kepemilikan umum dan kepemilikan bersama. Semua jenis kepemilikan ini bersifat tidak permanen.

Agar tatanan negara dapat berjalan sesuai dengan ril masing-masing, maka semua faktor yang ada dalam sebuah negara haruslah berjalan seiringan. Agama, ekonomi dan militer. Tiga faktor inilah yang menentukan kuat tidaknya sebuah negara. ${ }^{24}$

\section{Latar Belakang Pemikiran}

Al-kharaj, sebagai karya yang fenomenal, lahirnya karya ini tentunya memiliki latar belakang yang panjang. Tidak hanya atas permintaan raja Harun Arrasyid, namun juga dipengaruhi faktor lain, baik faktor internal, ataupun faktor eksternal.

Faktor intern yang mempengaruhi pemikiran Abu Yusuf adalah saat ia masih muda. Kecintaannya pada ilmu pengetahuan dan guru yang mendidiknya turut andil dalam proses pembentukan pola pikirnya. Pemikirannya sedikit berbeda dengan guru-gurunya, karena menghindari taqlid. Abu Yusuf lebih mengedepankan asas rasionalitas dalam menetapkan kebijakan. Hal ini dipengaruhi keadaan sosial yang terjadi pada saat ini. Sehingga setiap fatwa atau pun penetapannya tidak keluar dari konteks masalah.

Sedangkan faktor dari luar yang mempengaruhi pola pikirnya adalah pemerintahan pada saat ini. Model pemerintahan yang absolut, tidak bisa diganggu gugat, menyebabkan banyak terjadi pemberontakan atas kebijakan pemerintah. Politik yang tidak stabil dan penindasan yang dilakukan pemerintah untuk menekan masyarakat, membuat kitab al-kharaj lebih banyak mengoreksi kebijakan-kebijakan yang dilakukan oleh pemerintah. ${ }^{25}$

Tugas pemerintah adalah memberikan pengayoman terhadap masyarakatnya. Kebijakankebijakan yang diambil seharusnya tidak hanya menguntungkan bagi negara, tapi juga menguntungkan bagi masyarakatnya. Tanggung jawab sosial adalah titik tekan yang hendak disampaikan dalam kitab al-kharraj. Apaah arti menguntungkan bagi negara, tapi menyengsarakan rakyatnya. Makanya, dalam setiap keiajakn yang diambil, aspek sosial inilah yang hendak disampaikan. Bermanfaat bagi masyarakat, bermanfaatt bagi negara juga.

\footnotetext{
24 https:/ / www.nu.or.id/post/read/101873/pemikiran-abu-yusuf-soal-ekonomi-negara-dalam-kitab-al-kharaj

${ }^{25}$ Naili Rahmawati, Pemikiran Ekonomi Islami Abu Yusuf, makalah disajikan pada situs pemikiran ekonomi Abu Yusuf, 03 Rabiul Awal 1431 H, Mataram, h. 1-2.
} 


\section{Abu Yusuf dan Pajak (Konsep Dalam Kitab Al-Kharaj dan Relevansinya}

Abu Yusuf menyarankan agar negara mengambil tindakan dengan mengambil bagian dari hasil pertanian, khususnya kepada para penggarap daripada menarik sewa dari lahan pertanian. Selain lebih adil bagi penggarap, cara ini juga dinilai lebih banyak memberikan hasil produksi dan kemudahan dalam pertanian. Para penggarap akan lebih fokus untuk menghasilkan panen dari pada memikirkan nilai pungutan yang harus diserhkan kepada negara.

Prinsip yang dibuat oleh Abu Yusuf saat ini dikenal dengan istilah canons of taxation, yaitu asas pemungutan yang digunakan dalam pajak, meliputi : asas persamaan, keadilan dan kemampuan (equality, equity, and ability); asas kepastian (certainty); asas kenyamanan pembayaran (convenience of payment); dan asas efisiensi (economy of collection).

Dengan prinsip canons of taxation, pemerintah memperhatikan kesiapan dan kesanggupan para wajib pajak untuk membayar, memberikan waktu longgar agar tidak memberatkan. ${ }^{26}$

Abu yusuf mencontohkan sikap Umar ibn Khattab yang lunak pada Bani Tlaghlab. Sebagai penduduk yang anti pajak, Abu Bakar tidak mewajibkan pajak bagi mereka, tapi menerapkan sedekah. Kebijakan yang diambil lebih mengedepankan unsur manfaat demi mencegah mudharat ${ }^{27}$.

Demi mencegah adanya kesalahan dalam praktik perpajakan, Abu Yusuf mengatur sentralisasi administrasi dalam pembuatan kebijakan perpaja kan. Contoh $^{28}$ :

1. Departemen perpajakan menetapkan presentase pajak sesuai dengan jenisnya. Mengatur jumlah nominal tarif yang wajib ditagih dan aturan hukumnya. (Charging a justifiable minimum)

2. Departemen perpajakan dilarang melakukan pemerasan, baik melalui ancaman atau pun hal lain yang berkonotasi pada penindasan. Wajib pajak berhak untuk melakukan kewajibannya tanpa harus ada penindasan terlebih dahulu dari oknum perpajakan. Karena efek dari penindasan ini akan berpengaruh pada berkurangnya jumlah wajib pajak karena melarikan diri dari wajib pajak. (No oppression of tax-payers)

3. Pemerintah harus melakukan pemeliharaan atas aset-aset yang dimiliki. Baik aset tetap, ataupun aset tidak tetap. Karena aset yang dipelihara akan lebih mudah diketahui nilai asetnya, sehingga pengeluaran negara akan bisa dimaksimalkan. (Maintenance of a bealthy treasury).

4. Antara departemen perpajakan dan wajib pajak harusnya bersinergi. Karena keduanya memiliki keuntungan yang sama. Pajak menerima keuntungan dari wajib pajak, sedangkan wajib pajak akan menerima keuntungan dari infrastruktur yang dibangun oleh negara yang akan mempermudah operasional produksinya. Dengan bersinergi, maka negara akan memiliki ke-

\footnotetext{
${ }^{26}$ Adiwarman Azwar Karim, Sejarah Pemikiran Ekonomi Islam (Jakarta: RGP: 2004), h.14-15.

${ }^{27}$ Yusuf al-Qardhawi, Karakteristik Islam (Jakarta: Rabbani press: thn), h. 296

${ }^{28}$ Muh. Maksum, Ekonomi Islam Perspektif Abu Yusuf. El-Wasathiya: Jurnal Studi Agama, Vol 2 No 1 (2014)
} 
untungan yang besar, tidak hanya pendapatan pajak, tapi juga loyalitas para wajib pajak. (Benefiting both government and tax-payers)

5. Dalam menentukan pilihan antara yang memiliki keuntungan bagi departemen perpajakana dan wajib pajak, lebih diutamakan untuk memilih keuntungan bagi wajib pajak. Karena negara membutuhkan peran wajib pajak untuk mendapatkan pemasukan dan pendapatan guna membiayai anggaran belanja negara. Ketika departemen perpajakan memaksakan kehendak dengan cara melakukan penindasan, maka para wajib pajak akan lari dan menghindari membayar pajak. Pemerintah yang akan dirugikan jika hal ini terjadi. (In choosing between alternative policies having the same effects on treasury, preferring the one that benefits tax-payers).

Abu Yusuf tidak setuju praktik pajak dalam pertanian. Yang bisa dilakukan dalam pertanian adalah mewajibkan pajak atas hasil pertanian. Karena pertanian tidak selalu menguntungkan. Ada faktor alam dan faktor lain yang menyebabkan berhasil atau tidaknya pertanian. Ketika belum berhasil tapi ditarik untuk membayar pajak, maka yang dirugikan adalah pihak petani.

Sistem pajak tetap (lump sum system) haruslah diganti dengan pajak proporsional atas hasil pertanian. Sistem pajak lebih manusiawi dan mencerminkan keadilan bagi pelaku ekonomi. Selain itu sistem ini juga mampu menjadi automatic stabilizer bagi perekonomian, sehingga tidak terjadi fluktuasi jika perekonomian mengalami keguncangan efek dari tersendatnya perekonomian. ${ }^{29}$

Penekanan dalam kitab al-kharraj ini adalah bagaimana mengelola keuangan negara dalam bentuk pajak, pendapatan negara dan pengeluaran negara sesuai dengan syariat Islam yang mengedepankan keadilan, mencegah kedzaliman dan menciptakan kesejahteraan bagi masyarakatnya. $^{30}$

Pajak dikenakan pada tanah non-muslim yang berada di negara islam. Praktik ini pertama kali dilakukan atas tanah Khibar, pada masa Rasulullah SAW. Perhitungannya berdasarkan pada produktivitasnya yang mana ditentukan berdasarkan atas jenis tanaman, metode irigasi dan tingkat kesuburan lahan pertanian. ${ }^{31}$

Lebih jelasnya, bahwa pajak ini dikenakan atas beberapa kategori, yaitu:

1) Berada pada wilayah perjanjian damai antar negara islam dan penduduk non-muslim.

2) Tanah milik pribadi, bukan tanah pemberian dari pemerintah. ${ }^{32}$

\section{Metode Penetapan Tarif Pajak}

Untuk menetukan tarif pajak, Abu Yusuf menggunakan dua metode, Yaitu ${ }^{33}$ :

\footnotetext{
29 P3EI UII Yogyakarta, Ekonomi Islam (Jakarta, Rajagrafindo Persada: 2008), h.107.

30 Abu Yusuf, Kitab al-Kharaj, (Kairo: al-Matba'ah as-Salafiyah, 1302 H). Hlm. 3

31 Adi Warman Karim, Sejarah Pemikiran Ekonomi Islam, (Jakarta: ITT Indonesia, 2001). Hlm. 32

32 Euis Amelia, Sejarah Pemikiran Ekonomi Islam: dari masa klasik. hinggakontemporer.. Pustaka Asatruss, 2005125
} 


\section{Abu Yusuf dan Pajak (Konsep Dalam Kitab Al-Kharaj dan Relevansinya}

1. Metode Misahah (a fixed tax rate). Misahab/wadrifah adalah tarif pajak tetap sesuai undang-undang yang berlaku tanpa mempertimbangkan jumlah dasar pengenaan pajaknya. Prinsip misabah pertama kali diterapkan pada awal masa Dinasti Abbasiyah. Prinsip ini didasarkan pada ukuran dan luas lahan dengan mengenyampingkan jenis tanah dan tingkat kesuburannya. Sistem ini tidak melihat sistem irigasi yang digunakan dan jenis tanaman yang dihasilkannya.

2. Metode muqasamah (a proportional tax). prinsip muqosamah adalah tarif dengan presentase tetap tanpa memperhatikan jumlah yang dijadikan dasar pengenaan pajak. Contohnya, PBB sebesar 0,5 persen, pajak pertambahan nilai sebesar 10\%, dan bea perolehan hak atas tanah dan bangunan sebesar 5\%. tarif proporsional ini hanya menggunakan satu tarif yang presentasenya tetap, tidak berubah. Sedangkan dalam pertanian, rasionya didasarkan atas jenis tanaman, jenis tanah dan sistem irigasi. ${ }^{34}$

Abu Yusuf menggunakan tarif yang berbeda-beda atas setiap tanah yang dikenakan pajak, misalnya:

1) $40 \%$ yang sistem irigasinya menggunakan hujan alami

2) $30 \%$ yang sistem irigasinya menggunakan irigasi buatan

3) $25 \%$ untuk tarif pajak saat musim panas

Keuntungan dari penerapan metode muqasamah adalah: Pertama, meningkatkan pendapatan departemen perpajakan (bait al-maal). Kedua, mencegah ketidak adilan bagi yang membayar pajak.

\section{Konsep Al-Kharaj dan Relevansinya Dalam Ekonomi Saat Ini}

Konsep pajak Abu Yusuf memiliki reevansi dengan konsep pajak dalam ekonomi saat ini, khususnya konsep pajak yang ada di indonesia.

1. Konsep Kharaj pada Pajak Bumi dan Bangunan (PBB)

Pajak Bumi dan Bangunan (PBB) adalah pajak yang dipungut atas tanah dan bangunan karena adanya keuntungan atau kedudukan ekonomi yang lebih baik bagi orang atau badan yang mempunyai sesuatu hak atasnya atau memperoleh manfaat dari padanya. ${ }^{35}$

Konsep PBB yang dimanfaatkan oleh indonesia dimanfaatkan sebagai pemasukan dan diakui sebagai pendapatan negara dari sektor pajak. Demikian juga konsep al-kharaj digunakan pada

\footnotetext{
${ }^{33}$ Martina Nofra Tilopa, "Pemikiran Ekonomi Abu Yusuf Dalam Kitab Al-Kharaj”. AL-INTAJ Vol. 3, No. 1, Maret 2017

${ }^{34}$ Euis Amelia, Sejarah Pemikiran Ekonomi Islam: dari masa klasik hinggakontemporer.. Pustaka Asatruss, 2005. h 128

35 Wikipedia, Pajak Bumi dan Bangunan, dalam https://id.wikipedia.org/wiki/ diakses pada tanggal 17 Februari 2021.
} 
masa Abu Yusuf. Keduanya digunakan pemerintah untuk membiayai pengeluaran-pengeluaran negara.

Perbedaan yang paling mencolok adalah beban yang diberikan pada keduanya. PBB dibebankan atas semua jenis tanah yang berada di wilayah negara, sedangkan kharaj hanya dibebankan pada lahan pertanian saja. Selain itu, kharaj dikenakan atas tanah yang dikelola oleh non-muslim, sedangkan PBB dikenakan pada tanah dan bangunan yang dimiliki oleh semua warga negara.

PBB dipungut didasarkan pada Undang-undang No. 12 Tahun 1994 pajak bumi dan bangunan yang memberikan keuntungan, maka wajar jika diwajibkan memberikan sebagian keuntungan tersebut kepada negara melalui pajak ${ }^{36}$.

\section{Praktik Usyurpada Bea Cukai}

Bea cukai dikenal sebagai pungutan yang dipungut atas suatu kegiatan perdagangan yang menggunakan lalu lintas barang dan perbuatan lainnya atas ketentuan peraturan dan undangundang. Barang-barang yang dikenai cukai memiliki sifat dan karakteristik berdasarkan peraturan perundang-undangan, yaitu barang-barang yang dalam pemakaiannya perlu dibatasi atau diawasi. ${ }^{37}$

Pajak bea cukai dalam istilah Abu Yusuf adalah usyur. Usyur petama kali dipraktikan pada masa Umar Bin Khatab. Bermula dari tarif yang dikenakan pedagang muslim saat berdagang di daerah kafir harbi sebesar 1/10, maka sebagai gantinya, pedagang dari negara lain dikenakan 5\% saat memasuki wilayah negara Islam. Tarif tersebut dikenakan kepada Drimih. Sedangkan pada pedagang muslim dikenakan $2,5 \%{ }^{38}$

Di Indonesia, bea cukai juga diperlakukan khusus barang-barang dari luar negeri dengan ketentuan yang diatur oleh undang-undang. Tujuannya adalah melindungi masyarakat Indonesia dari membludaknnya produk-produk luar negeri. Selain itu juga melindungi industri UMKM dalam negeri dari serbuan barang asing yang harganya lebih rendah dari produk dalam negeri.

Usyer dan bea cukai memiliki kesamaan, yaitu:

1. sama-sama pajak yang dipungut untuk melindungi masyarakat dan untuk kemaslahan umat.

2. Usyur dikenakan untuk individu berdasarkan agama. Sedangkan cukai dikenakan individu yang membawa barang dari/ke luar negeri berupa barang yang dikenai cukai.

3. Usyur dan bea cukai dibayarkan pada pintu masuk dan pintu keluar negara

4. Usyur ditarik jika memiliki kadar sebesar 200 dirham sebagai batas minimal, sedangkan bea cukai berdasarkan nilai nominal pada barang yang dibawa.

\footnotetext{
${ }^{36}$ Gushfahmi, Pajak Menurut Syriah, (jakarta. Rajawali Pers, 2007), h. 32

${ }^{37}$ Casavera, Perpajakan Yogyakarta : Graha Ilmu, 2009

38 Ahmad Muti, Keuangan Publik. Islam menurut kitab Al kharaj Abu Yusuf Relevansinya dengan APBN, jakarta : UI,. Hlm 145
} 


\section{Abu Yusuf dan Pajak (Konsep Dalam Kitab Al-Kharaj dan Relevansinya}

\section{Rikhaj pada Barang Tambang}

Dalam rikhaj Abu Yusuf membebankan tarif 1/5 dari barang. Di Indonesia berlaku hukum bagi pelaku penambangan batu mineral, 4\% dibayarkan kepada Pemerintah pusat, 6\% diberikan kepada pemerintah daerah dari total keuntungan. Ketentuan tersebut berdasarkan pada Undang-undang No. 4 tahun 2009 tentang pertambangan mineral dan batu bara pasal Pasal 129 .

\section{SIMPULAN}

Dari penjelasan panjang lebar di atas dapat disimpulkan, bahwa al-kharaj menggantikan sistem waziifah dengan sistem muqassamah. Sistem waziffah dihitung berdasarkan nilai tetap, tanpa membedakan kemampuan wajib pajak. Sedang sistem muqassamah adalah sistem pajak berlaku berdasarkan nilai yang berubah-ubah. Penerapan konsep al-kharaj hampir sama dengan penerpan pajak bumi dan bangunan di Indonesia. Ushr menyerupai bea cukai dan rikhaj disamakan pajak atas tambang. Isi dalam kitab yang ditulis oleh Abu Yusuf masih relevan dengan kebijakan yang diambil oleh pemerintah indonesia..

\section{DAFTAR PUSTAKA}

Al-Kaaf, Abdullah Zakiy. Ekonomi dalam Perspektif Islam. Bandung: Pustaka Setia, 2002.

al-Qardhawi, Yusuf. Karakteristik Islam (Jakarta: Rabbani press: tthn)

Amelia, Euis, Sejarah Pemikiran Ekonomi Islam: dari masa klasik hingga kontemporer.. Pustaka Asatruss, 2005.

Arfah, Tina; Jamilah, Putri, "Keuangan Publik Dalam Perspektif Ekonomi Islam". Jurnal ISLAMIKA, Vol. 3, No. 2 (2020)

Brinton, Crane, Pengantar Ilmu Politik. Bandung: Binacipta, 1980.

Casavera, Perpajakan. Yogyakarta: Graha Ilmu , 2009

Gushfahmi, Pajak Menurut Syriah, (jakarta. Rajawali Pers, 2007)

Karim, Adi Warman, Sejarah Pemikiran Ekonomi Islam, (Jakarta: ITT Indonesia,

Karim, Adiwarman Azwar, Sejarah Pemikiran Ekonomi Islam (Jakarta: RGP: 2004)

Khoerulloh, Abd. Kholik; Komarudin, Omay; Abdillah, Lukman Fauzi, “Konsep Pajak Dalam Perspektif Abu Yusuf dan Asy-Syatibi”. An-Nisbah: Jurnal Ekonomi Syariah Volume 07, Nomor 01, April 2020

Maksum, Muh., Ekonomi Islam Perspektif Abu Yusuf. El-Wasathiya: Jurnal Studi Agama, Vol 2 No 1 (2014)

Mesr, Alimin, "Kajian atas Kredibilitas Imam Abu Hanifah di Bidang Hadis". AL-FIKR Volume 14 Nomor 3 Tahun 2010 
Muti, Ahmad, Keuangan Publik Islam Menurut kitab Al Kharaj Abu Yussuf Relevansinya dengan APBN, Jakarta : UI, 2001.

Oky, Rachmatullah, “Teori Pajak Menurut Abu Yusuf Sebuah Alternatif Solusi Perpajakan Di Indonesia”. Iqtishoduna Vol. 8 No. 1 April 2019

P3EI UII Yogyakarta, Ekonomi Islam (Jakarta, Rajagrafindo Persada: 2008) pada tanggal 17 Februari 2021.

Rahmawati, Naili, Pemikiran Ekonomi Islami Abu Yusuf, makalah disajikan pada situs pemikiran ekonomi Abu Yusuf, 03 rabiul awal 1431 H, Mataram,

Sadam, Muhammad, Ekonomi Islam (Jakarta: Taramedia, 2002)

Sumardi, Dedy, "Legitimasi Pemungutan Jizyah Dalam Islam:Otoritas Agama Dan Penguasa". Media Syariah, Vol. XV No. 2 Juli-Desember 2013

Tandilino Albertus, "Penerapan Pajak Dalam Meningkatkan Penerimaan pajak Penghasilan Final Sektor Umkm Di Kota kendari”. Jurnal Progres Ekonomi PembangunanVoume 1 Nomor 1,2016

Tilopa, Martina Nofra, "Pemikiran Ekonomi Abu Yusuf Dalam Kitab Al-Kharaj". AL-INTAJ Vol. 3, No. 1, Maret 2017

Wikipedia, Pajak Bumi dan Bangunan, dalam https://id.wikipedia.org/wiki/ diakses

Yulianti, Rahmani Timorita, "Pemikiran Ekonomi Islam Abu Yusuf". MUQTASID Jurnal Ekonomi dan Perbankan Syariah, Vol 1, No 1 (2010)

Yusuf, Abu, Kitab al-Kharaj, (Kairo: al-Matba'ah as-Salafiyah, tt).

"Fungsi Pajak", https://www.pajak.go.id/id/fungsi-pajak, diakses pada 15 Februari 2021.

"Menkeu: Pajak Merupakan Tulang Punggung Nasional", https://www.kemenkeu.go.id/publikasi/berita/menkeu-pajak-merupakan-tulangpunggung-nasional/ diakses pada 15 Februari 2021.

"Pemikiran Abu Yusuf soal Ekonomi Negara dalam Kitab Al-Kharaj", https://www.nu.or.id/post/read/101873/pemikiran-abu-yusuf-soal-ekonomi-negaradalam-kitab-al-kharaj diakses pada 20 Februari 2021 
Abu Yusuf dan Pajak (Konsep Dalam Kitab Al-Kharaj dan Relevansinya

76 | FENOMENA, Vol. 20 No. 1 (Januari - Juni 2021) 